\title{
銅の拡散接合性に及ぼす表面処理の影響*
}

\author{
鈴村暁男**，恩沢忠男**，田村 博**
}

\section{Effects of Surface Treatments on Diffusion Weldability of Copper*}

by Akio Suzumura**, Tadao Onzawa**, Hiroshi Tamura**

\begin{abstract}
The effects of various surface treatment methods such as emery paper polishing, buff polishing, argon ion sputtering, and silver ion plating on the diffusion weldability of copper have been investigated by scanning electron microscopy and Auger electron spectroscopy of the surfaces, in addition to mechanical and microscopic tests of the joints.

Buff polishing was more effective than emery paper polishing because of giving the smaller surface roughness, but the both methods left alumina powder on the surfaces. Argon ion sputtering for five minutes removed the alumina and improved the weldability. Silver ion plating after argon ion sputtering showed remarkable improvement in the weldability, and the joint welded for ten minutes at $400^{\circ} \mathrm{C}$ after this treatment showed almost the same tensile strength as that of the base metal. This result demonstrates that silver ion plating is superior to silver foil interlayer method in improvement on the diffusion weldability of copper.
\end{abstract}

1. 緒

\section{言}

銅の拡散接合性汇影響する因子として接合温度，圧 力, 時間の他に接合表面の状態が挙げられる，接合面の 表面処理に関する研究としては，表面あらさの影響1), グロー放電による表面処理 2 , イオン蒸着処理 3 などの 効果を調べた研究が数例あるだけである。そてで本研究 では接合母材として銅を用い，表面の研摩法あるいはア ルゴンイオン衝撃処理による表面の清浄度の違いをマイ クロオージェ分析によって調へ，また継手の引張試験， 組織観察, 破面観察等を行って,とれらの表面処理がと くに接合温度が $200^{\circ} \mathrm{C} \sim 500^{\circ} \mathrm{C}$ という比較的低い温度籍围 でかつ接合変形率 (接合部断面増加率) を数パーセント 以内に抑えた場合の銅の拡散接合性に及涩す影響を検討 した。さらにインサート金属挿入法としてのイオン蒸着 法を䇴を用いた接合と比較した。

\section{2. 供試材およひ実験方法}

接合母材としてはタフピッチ銅の直径 $10 \mathrm{~mm}$ の丸棒 を用いた，接合試片，接合状態および引張試片の形状を Fig. 1 に示す.とこで接合端面のテーパは接合を行い易 くするためにつけてある.イオン蒸着用には純度 99.999 \%の高純度銀を用い, また比較のため厚さ $5 \mu \mathrm{m}$ の銀箔

*原稿受付 昭和55年 9 月 1 日

**正 員 東京工業大学 Member, Tokyo Institute of Technology

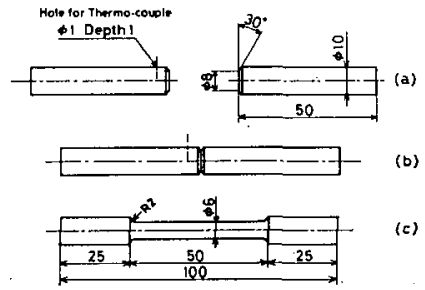

Fig. 1 Shapes and dimensions of the specimens; (a) Weld specimen '(b) Joint (c) Tensile specimen

および金箔をインサート金属として用いた．インサート 金属は入手したあのをアセトンにより脱脂洗浄して用い た。

端面を旋盤加工した武片は，石ケンで洗浄後トリクロ ロエチレンおよびアセトンで脱脂した。 その後接合面を 1500番のエメリー紙まで研摩したのち粒径 $1 \mu \mathrm{m}$ のアル ミナを用いてバフ研摩し，さらにアセトン中で15分間超 音波洗浄を行った。

アルゴンイオン衛撃処理は次の手順により行った。す なわち試片を装置内に装填後, 装置内の残留空気濃度を 極力低下させるために一度 $5 \times 10^{-3}$ torr まで排気したの ちアルゴンガス（純度99.998\%）を 2.0 torr まで導入す る.そして再び $5 \times 10^{-3}$ torr まで排気したのち $1.5 \times$ $10^{-2}$ torr のアルゴンガス雾囲気とした。 この中でフィラ メント（+）と試片（-）の間に $1 \mathrm{kV}$ の電圧を印加し 


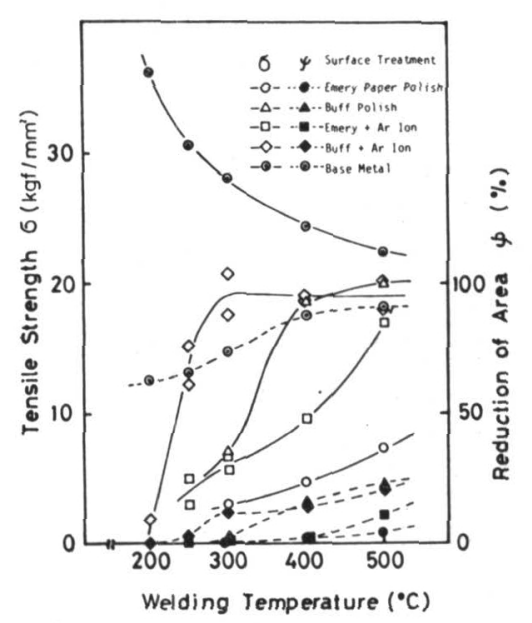

Fig. 2 Effects of the surface treatments and welding temperature on the mechanical properties of the joints welded without interlayers ; welding time : 10 min., welding pressure: $3 \mathrm{kgf} / \mathrm{mm}^{2}$.

グロー放電を起こしてイオン衝撃処理を行った。このと き放電電流は $50 \mathrm{~mA}$ となるように真空度および印加電 圧を微調整した. イオン衙撃は通常20分間行った。

銀イオン蒸着処理は, アルゴンイオン衝撃処理後引き 続きフィラメントと試片の間に電圧を印加しながら, 夕 ングステン製のバスケット型フィラメントに装填された 銀を抵抗加熱により蒸発させて行った。

接合は, 陚片を真空蒸着装置加ら一度大気中に取り出 した後拡散接合装置内に装填し, $5 \times 10^{-5}$ torr $の$ 真空中 で $200^{\circ} \mathrm{C} \sim 500^{\circ} \mathrm{C}$ 亿高周波誘導加熱し, 所定の温度に達し たのち接合面に $3 \mathrm{kgf} / \mathrm{mm}^{2}$ の圧力を加えて行った．接 合時間は10分間とした。

\section{3. 実験結果および考察}

\section{1 直接接合性におよぼす表面処理の効果}

まずエメリ一紙研摩とバフ研摩およびそれぞれの処理 のあとにアルゴンイオン衝撃処理を行った試片をイン サート金属を用いずに直接接合しその接合温度と継手強 さの関係を検討した. その結果を Fig. 2 に示す. エメ リー紙研摩による場合は $500{ }^{\circ} \mathrm{C}$ で接合した継手であ引張 強さは $7 \mathrm{kgf} / \mathrm{mm}^{2}$ 程度しかないが，バフ研摩処理する 之接合性は著しく改善され 400 C で接合した継手でも引 張強さは $18 \mathrm{kgf} / \mathrm{mm}^{2}$ 程度に達している、またアルゴン イオン衝撃を施した試片では接合温度が $250^{\circ} \mathrm{C}$ とかなり 低い場合でむ $12 \mathrm{kgf} / \mathrm{mm}^{2}$ を越える継手強さが得られ， $300^{\circ} \mathrm{C}$ で接合した継手では $20 \mathrm{kgf} / \mathrm{mm}^{2}$ を越えている. しかし, 接合圧力が $3 \mathrm{kgf} / \mathrm{mm}^{2}$ で10分間接合した場合,

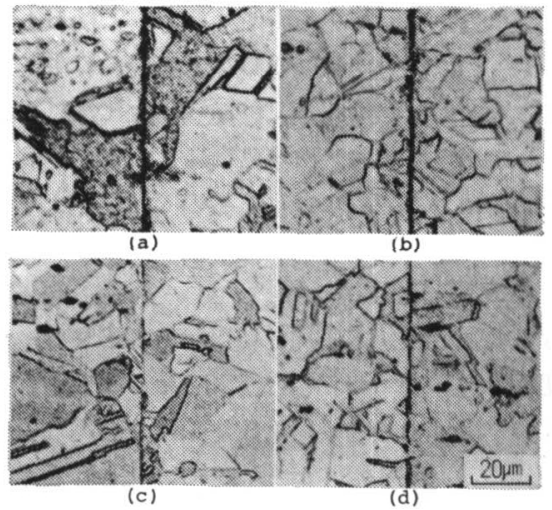

Fig. 3 Microstructures of the joints welded at $300^{\circ} \mathrm{C}$ without interlayers after various surface treatments. (a) Emery paper polishing (b) Emery paper polishing and Ar ion sputtering (c) Buff polishing (d) Buff polishing and $\mathrm{Ar}$ ion sputtering

$500^{\circ} \mathrm{C}$ 以下の温度での直接接合ではいずれの表面処理を 施した試片でも母材の引張強さよりは低い継手強さしか 得られなかった. なお Fig. 2 で母材の引張強さおよび 絞りは, 接合継手と同じ熱サイクルを受けた後の值を示 している.

Fig. 3 は種々の表面処理を施した試片を 300 C で直接 接合した継手の接合部断面の顕微鏡組織である. (a) の エメリー紙研摩処理の試片および (b) のエメリー紙研摩 後アルゴンイオン衙撃処理を施した試片の接合部はどち ら屯接合界面が明膫に観察され, 多数の空隙が存在して いると考えられる。一方 (c) のバフ研摩処理の試片およ び (d) のバフ研摩後アルゴンイオン沺撃処理を施した試 片の接合部では，接合界面は直線状に観察されるが (a), (b)に比ぺてはるかに密着性が良いととがわかる。後の Fig. 5 であ観察されるがエメリー紙研摩処理に比べてバ フ研摩処理では表面のあらさが格段に小さくなってい る. 拡散接合性におよぼす接合表面のあらさの影響は, 接合压力や接合温度, 接合表面の清浄度等に関連し一概 には言えないが，一般に表面あらさが小さくなる程接合 部での空隙は小さくなり, 空隙の収縮にクリープ変形に 加えて燒結過程と類似の現象が作用するため密着化が促 進される1). Fig. 2 亿おいてエメリー紙研摩処理に比べ てバフ研摩処理した試片の接合性が大幅に向上した主な 原因は，乙の表面あらさの減少によると考えられる。

Fig. 4 はバフ研摩処理した表面とバフ研摩後アルゴン イオン衝摩処理した表面を比較したあのである.アルゴ ンイオン衝撃処理の効果に関しては, イオン衝撃処理に よって表面の污れが取り除かれ内部の凹凸が明瞭にな 
るという報告2)ああるが，本研究においてはあともとバ フ研摩によって鏡面仕上げされた表面のためか，イオン 衝撃後も表面の凹凸に関しては顕著な変化は見られてい ない.したがってイオン衝撃処理による接合性の改善は 接合表面のあらさの変化によるあのではないと考えられ る.

そこでこれらの表面をマイクロオージェ分光器 (AES) によって検査した。 本研究で使用した AES は最高到達 真空度が $1 \times 10^{-10}$ torr であり，イオンビーム方式によ り $2 \times 10^{-5}$ torr 中でアルゴンイオン衝揧を行ない直ちに （数秒以内で） $2 \times 10^{-8}$ torr 程度に復州させ表面分析を

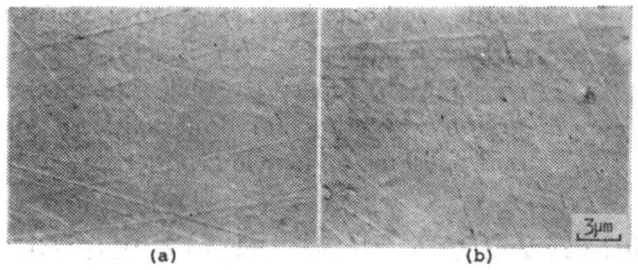

Fig. 4 Scanning electron micrographs of the surfaces for welding, (a) after buff polishing (b) after buff polishing and Ar ion sputtering
行うことができる.Fig. 5 はエメリー紙研摩した表面(a) とバフ研摩した表面 (b) の走査電顕写真で, 写真中 A, B， Cで示した部分を AES により元素分析した. Fig. 6 (a) は写真中Aで示した介在物と思われる部分の AES の 分析結果ならびに AES 中で 3 分間イオン衝撃を行った 後の同じ部分の分析結果である。乙れによると大気中で エメリー紙研摩しアセトン中で15分間超音波洗浄した試 片の表面には炭素や酸素の他にアルミニウムが検出され る、このアルミニウムは研摩剂のアルミナと思われる． この表面にアルゴンイオン衝撃処理を 3 分間行うと酸素 とアルミナは大幅に隇少することがわかる．Fig. 6(b) は 写真中 B 部のイオン衝撃前および 1 分間のイオン衝撃後 ならびに 5 分間のイオン衝撃後の AES 分析結果と, 写 真中 $\mathrm{G}$ 部のイオン衝撃前の AES 分析結果で, 共に1000 $\sim 1500 \mathrm{eV}$ の間の屯のを示している. Bの介在物と思わ れる部分では明瞭にアルミナが検出される.これあやは りバフ研撃剂に用いたアルミナと考えられる. 同じ場所 を 1 分間イオン衝撃するとアルミナはかなり減少し， 5 分間イオン衝撃した後ではほとんど検出されなくな る、 C部ではとくに介在物らしきものは認められないが AES の分析結果によるとわずかではあるがアルミナが 検出される。このととからバフ研撃によって鏡面に仕上
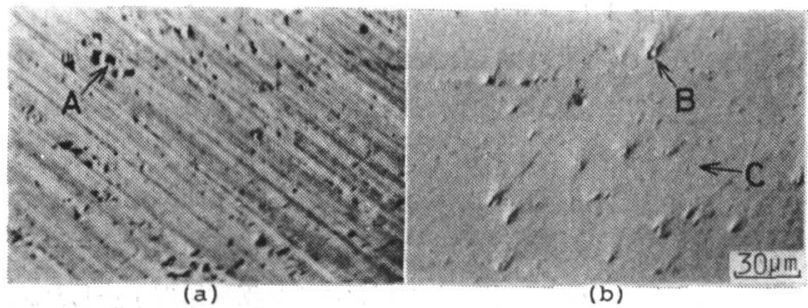

Fig. 5 Scanning electron micrographs of copper surfaces, where the sites, A, B, and C were analyzed by micro Auger electron spectrocsope; (a) aftei emery paper polishing (b) after buff polishing
げられその後アセトン中で超音波洗浄した面 にも微小なアルミナ粒が层汎に存在している ことがわかる，乙の部分あやはり 5 分間のイ オン衝撃後にはアルミナは検出されなくなっ た. 確認のためエメリー紙研摩処理した試片 とバフ研摩処理した試片を真空蒸着装置内で アルゴンイオン衝撃した後, 表面を AES 分 析したところ, どちらあアルミナは検出され なかった．以上の結果から，アルゴンイオン 衝撃処理を行うと接合表面のあらさを変化さ

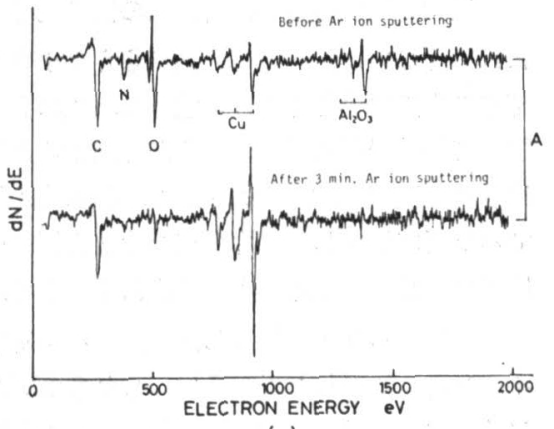

(a)

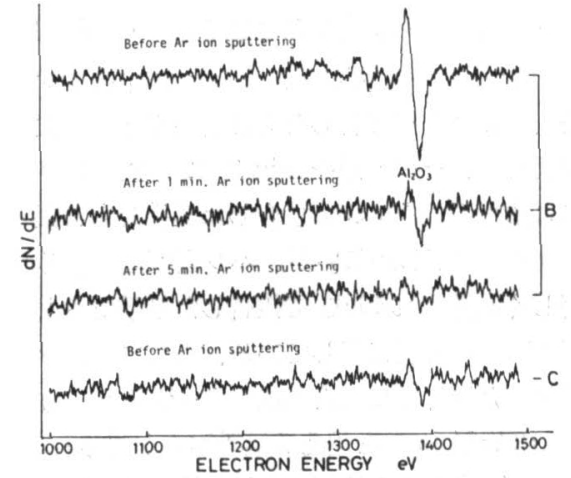

(b)

Fig. 6 Auger electron spectra at the sites indicated in Fig. 5. 
せるほどの効果は認められないが, 表面に存在している 污染層とくに研摩剂に用いるアルミナを除去することが でき，てれが接合性を改善させると考えられる。

\section{2 イオン蒸着によるインサート金属の挿入}

表面処理として, エメリ一紙研摩処理およびエメリー 紙研摩後バフ研摩を施した試片にアルゴンイオン衝撃後 銀をイオン蒸着し，銀蒸着膜をインサート金属として拡 散接合した銅継手の引張試験結果を Fig. 7 亿示す. 比較 のためエメリー紙研摩後アルゴンイオン衝撃処理した試 片を厚さ $5 \mu \mathrm{m}$ の銀箔および金䇴を用いて接合した継手 の引張武験結果も示した。

イオン蒸着は放電電庄 $1 \mathrm{kV}$ ，放電電流 $50 \mathrm{~mA}$ で20分 間アルゴンイオン衙撃処理をした後，引続き印加電圧 $1 \mathrm{kV}$ で行った。 イオン蒸着膜厚は $1 \sim 1.2 \mu \mathrm{m}$ となるよ うにした，従ってインサート金属の厚さは 2 2.4 $\mathrm{m}$ である. こてで蒸着膜厚は, あらかじめ種々の条件で蒸 着した場合の膜厚を干涉顕微鏡によって各々测定してお き,そとから推定した. 拡散接合圧力は $3 \mathrm{kgf} / \mathrm{mm}^{2}$, 接 合時間は10分間とした．銀䇴を用いて接合した継手は

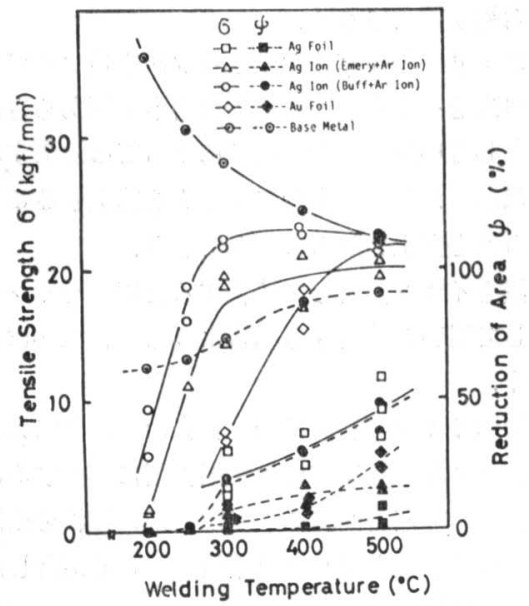

Fig. 7 Effects of various interlayer application methods on the mechanical properties of the joints.
$500{ }^{\circ} \mathrm{C} て ゙$ 接合した場合であ引張強さは $10 \mathrm{kgf} / \mathrm{mm}^{2}$ 程度 しかないが，金箔を用いた場合は 400 Cで接合してあ 15 $\mathrm{kgf} / \mathrm{mm}^{2}$ 以上の引張強さが得られ， 500 Cで接合すると 母材なみの強さが得られている。 この䇴を用いた接合に 関しては，著者らが以前に報告4)したように銅と全率固 溶する金を用いた場合の方が部分固溶しかしない銀を用 いた場合よりあ接合性を向上させるととがわかる。しか し銀をイオン蒸着によって接合面間に㨂入すると，金䇴 を用いた場合よりあさらに接合性が向上し，とくに300 「C以下で接合した場合にその差が著しい，また同じ銀の イオン蒸着であ接合面をバフ研摩した後に蒸着した方が エメリー紙研摩後に蒸着した場合よりも接合性を向上さ せ, $250{ }^{\circ} \mathrm{C}$ で接合した継手であ $17 \mathrm{kgf} / \mathrm{mm}^{2}$ 程度の引張 強さが得られている。

Fig. 8(a) は銀箔を用いて 300 C で接合した継手の引張 破面であり，(b) は銀をイオン蒸着して同じ温度で接合 した継手の破面で (c) は (b) をさらに高倍率で観察した あのである．箔を用いた方は銅母材表面と箔との間では く離し, 銅母材表面に研摩傷がそのまま残っていて銀と 銅の接合がほとんど進行していないととがわかる.とれ に対しイオン蒸着による方は銀と銅が大きな面積ではく 離したような跡は見られず, インサート金属と母材との 結合力が大きかったてとを示している．乙の点が Fig.7 に示された引張試験結果にあるように，銀箔を用いるよ りあイオン蒸着によってインサート金属を挿入する方が はるかに接合性を向上させる原因と考えられる．また，

Fig. 9 はエメリー紙研摩後銀をイオン蒸着した 表面 (a) とバフ研摩後イオン蒸着した表面 (b) を比較したもので ある．どちらの場合屯蒸着金属は蒸着表面上の核を中心 に成長していくと考えられるが，そのため蒸着表面は母 材表面の凹凸には大きな影響を受けている. バフ研摩後 にイオン蒸着した表面は全面一様な粒状の蒸着金属にお おわれているが，エメリ一紙研摩後に蒸着した表面はエ メリー紙研摩の凹凸に沿って蒸着面に起伏ができ，とく に研摩傷の谷間の部分には空陌が生じている。これがバ フ研摩後イオン蒸着して接合した継手に比較してエメ

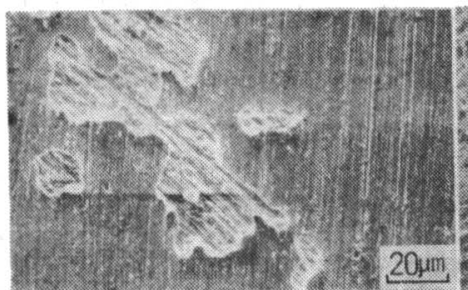

(a)

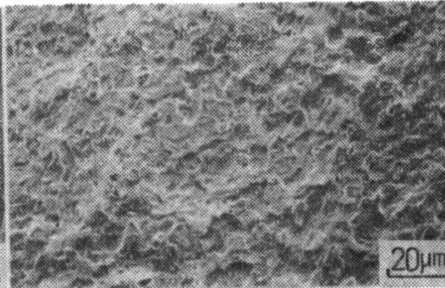

(b)

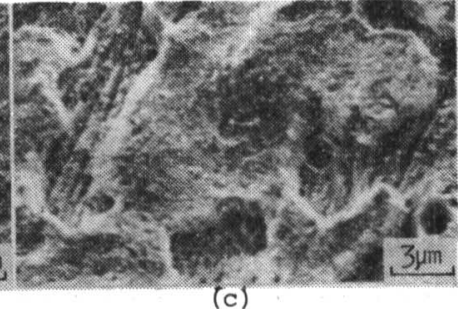

(c)

Fig. 8 Scanning electron fractographs of the joints welded at $300^{\circ} \mathrm{C}$ (a) with $\mathrm{Ag}$ foil interlayer (b) (c) with interlayer by Ag iron plating. 


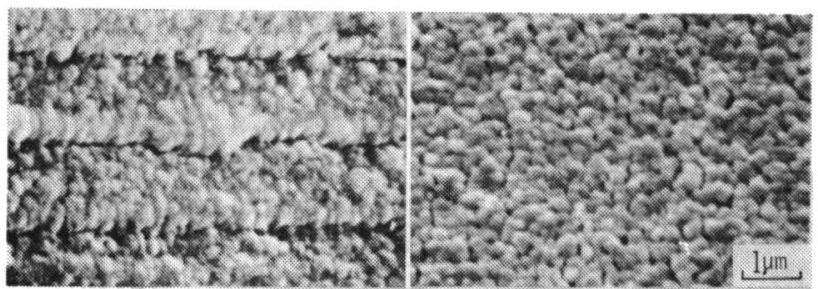

(a)

(b)

Fig. 9 Scanning electron micrographs of $\mathrm{Ag}$ ion plated surfaces; (a) ion plated after emery paper polishing (b) ion plated after buff polishing

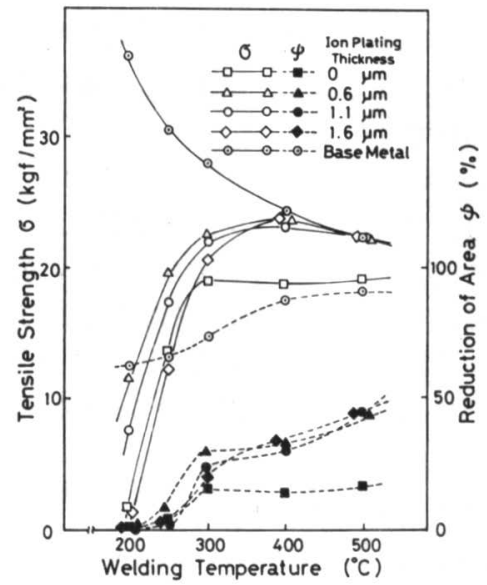

Fig. 10 Effects of interlayer thickness by $\mathrm{Ag}$ ion plating and welding temperature on mechanical properties of the joints.

リー紙研摩後に蒸着して接合した継手の強度が低い原因 と考えられる。

つぎに銀のイオン蒸着膜の厚さが接合性におよぼす影 響について検討した。Fig. 10 はバフ研摩後アルゴンイ オン衝撃した表面に銀をイオン蒸着し, 蒸着膜厚を 0 $1.6 \mu \mathrm{m}$ に変化させ, 接合温度を $200^{\circ} \mathrm{C} \sim 500^{\circ} \mathrm{C}$ とた場 合の継手の引張強さと絞りを示している。ここで $0 \mu \mathrm{m}$ はアルゴンイオン衝撃処理のまま蒸着を行わずに接合し たことを意味している．またインサート金属としての厚 さは膜厚の 2 倍となる. 銀をイオン蒸着すればアルゴン イオン衝撃のままのあのよりあ接合性は向上するが, $300^{\circ} \mathrm{C} \sim 500^{\circ} \mathrm{C}$ の温度範囲で接合した場合蒸着膜厚を 0.6 $\mu \mathrm{m}$ から $1.6 \mu \mathrm{m}$ に変化させても接合性はほとんど変化 せず，いずれの場合も $400{ }^{\circ} \mathrm{C}$ で接合すれば母材なみの引 張強さが得られている。しかし $200{ }^{\circ} \mathrm{C}$ とかなり低い温度 で接合した場合には膜厚が $0.6 \mu \mathrm{m}$ のときに最む継手強 さが大きくなった. 表面あらさ $\mathrm{R}_{\max }$ が $2 \mu \mathrm{m}$ 程度の鉄 母材表面に銀をイオン蒸着して接合した場合には, 膜厚 が $2.5 \mu \mathrm{m} \sim 5 \mu \mathrm{m}$ (インサート金属としての厚さは $5 \mu \mathrm{m}$
〜10 $\mu \mathrm{m}$ ）のときに 継手のせん断強さが最大 となるという報告3) があり，その原因は軟質 部に発生する 3 次元応力の効果および結晶粒 の微細化による強度の上昇機構と関連して説 明されている. 本研究の場合, その機構とし ては同様のととが考えられるが，母材表面が バフ研摩面であり表面あらさ $\mathrm{R}_{\max }$ が 0.1 $\mu \mathrm{m}$ 程度とかなり小さいため最適膜厚さが小 さくなったと考えられる。すすなわち最適蒸着 膜厚さは，接合温度や圧力による影響も大き いと考えられるが母材表面のあらさによっても大きく影 響され, 母材表面のあらさが小さいほど最適蒸着膜厚さ あ小さくなると考えられる。

\section{4. 結 論}

比較的低い温度における銅の拡散接合性におよぽす表 面処理の影響について検討した結果, 次の点が明らかに された。

（1）銅母材同士を直接接合する場合接合性は接合母材 表面のあらさに大きく影響され, エメリー紙研摩処理の まま接合するよりあバフ研摩処理して接合する方がはる かに接合性が改善される。

(2) エメリー紙研摩後およびバフ研摩後アルゴンイオ ン衝撃処理を行うと, どちらの場合も表面あらさはほと んど変化しないが，超音波洗浄によっては除去すること のできなかった研摩面上のアルミナを除去することがで き，接合性を向上させるととができる.

（3）銀をイオン蒸着して接合すると銀箔をインサート 金属として用いて接合する場合よりあ接合性がはるかに 向上する。

（4）銀のイオン蒸着面は銅母材表面の凹凸に大きく影 響され，エメリー紙研摩のまま銅表面に蒸着すると研摩 傷の谷に沿って蒸着面上にも谷が出来，てれを拡散接合 した場合の継手強さはバフ研摩後蒸着して接合した試片 の継手強さに比べて減少する。

本研究の遂行にあたり，AES 使用の御便宜をいただ いた防衛大学校の山下忠美教授をはじめとする方々，ま た実験に直接協力された当時東京工業大学学生津島正典 氏に厚く謝意を表します。

\section{参考 文 献}

1）大橋，橋本：拡散接合に関する研究（第 3 報）接合過程への表面 あらさの影響，本誌45-6 (1976） 485-491

2）大橋, 橋本：搥散接合に関する研究（第 1 報）グロー放電による表 面处理, 本誌45-1 (1976) 76-81

3） 大橋, 橋本：挞散接合に関する研究（第 5 報）イオンめっきによる インサート金属挿入法, 本誌45-8（1976）649-656

4）恩沢，鼻山，田村：挝散接合性におよぼすインサートメタルの効果 , 本声 45-8 (1976) 657-664 